\title{
Economic Viability of Smallholder Agroforestry and Beekeeping Projects in Uluguru Mountains, Tanzania: A Cost Benefit Analysis
}

\author{
Willickister R. Kadigi' ${ }^{1}$, Yonika M. Ngaga', Reuben M. J. Kadigi2 \\ ${ }^{1}$ Department of Forest and Environmental Economics, College of Forestry, Wildlife and Tourism, Sokoine University of \\ Agriculture, CHUO KIKUU, Morogoro, Tanzania \\ ${ }^{2}$ Department of Food and Resource Economics, School of Agricultural Economics and Business Studies, CHUO KIKUU, \\ Morogoro, Tanzania \\ Email: willickister@gmail.com,ngaga@sua.ac.tz,rmjkadigi@sua.ac.tz,rmjkadigi@yahoo.co.uk
}

How to cite this paper: Kadigi, W. R., Ngaga, Y. M., \& Kadigi, R. M. J. (2021). Economic Viability of Smallholder Agroforestry and Beekeeping Projects in Uluguru Mountains, Tanzania: A Cost Benefit Analysis. Open Journal of Forestry, 11, 83-107. https://doi.org/10.4236/ojf.2021.112007

Received: December 22, 2020

Accepted: March 30, 2021

Published: April 2, 2021

Copyright $\odot 2021$ by author(s) and Scientific Research Publishing Inc. This work is licensed under the Creative Commons Attribution International License (CC BY 4.0).

http://creativecommons.org/licenses/by/4.0/

\begin{abstract}
Agroforestry and beekeeping are widely promoted as prospective NatureBased Income Generating Activities (NIGAs) to improve livelihoods while at the same time enhancing biodiversity conservation in degrading agro-ecologies. These activities can diversify and increase famers' incomes and support instinctive biota and fauna resilience. However, evidence to showcase and compare their long-term benefits is scant. We use the case of Uluguru Mountains in Tanzania to evaluate and compare viability of agroforestry and beekeeping projects using the Cost Benefit Analysis (CBA) approach. The results of analysis yielded positive NPVs for both agroforestry and beekeeping projects at discount rates not higher than $8.2 \%$ and $8.5 \%$ respectively. Overall, the comparison of economic viability between agroforestry and beekeeping projects revealed that the former was relatively more profitable than the later in terms of both the NPV and Benefit Cost Ratio (BCR) criteria. However, the Internal Rate of Return (IRR) for beekeeping was slightly higher than that of agroforestry. Yet, we underscore the fact that these two projects can jointly be implemented to enhance livelihoods of farmers and support biodiversity conservation in the study area and other parts with similar agro-ecologies in developing countries. However, farmers in these agro-ecologies need to be supported by governments and non-government development partners in terms of training and inspiration to shift from orthodox farming to sustainable NIGAs.
\end{abstract}

\section{Keywords}

Uluguru Mountains, Uluguru Forestry Reserve, Cost Benefit Analysis, Net 
Present Values, Benefit Cost Ratios, Nature-Based Income Generating Activities

\section{Introduction}

Concerns over habitat losses, fragmentation of forests and misuse of natural ecosystems caused by unsustainable agriculture and other income generating activities are extensively reported in the literature as causing threats of extinction for some fauna and flora species (FAO, 2020a; FAO, 2020b; Vogt et al., 2019; Alroy, 2017; Giama, 2017; Venter et al., 2014; Laurance et al., 2012; Krauss et al., 2010; Tscharntke et al., 2008; Ewers \& Didham, 2006; Fahrig, 2003; Tilman \& Clark, 2014; Tilman et al., 1994). The recent UN Food and Agriculture Organization (FAO)'s global forest resources assessment report, for example, indicates that about 178 million hectares of forest have been lost worldwide over the past three decades (FAO, 2020a) and agriculture, is pointed out as the major cause of deforestation affecting a wide range of ecosystem services, including carbon sequestration, water quality, pollination, nutrient cycling, and soil retention just to mention few (Dale \& Polasky, 2007). In line with this understanding, the State of the World's Forests (SOFO) report on the status of forests identifies actions that can be taken to combat deforestation and increase the contribution of forests and trees that are necessary to accelerate progress towards the 17 Sustainable Development Goals (SDGs) which is the central framework for guiding development policies throughout the world (FAO, 2020b). In this regard, the global community is urged to promote the adoption of policy and technological innovations that enhance efficiency in agricultural production, biodiversity conservation and sustainable forest value chains.

The need to conserve biodiversity has even received an extra courtesy since 2010 following the Aichi-Nagoya Declaration (Target 7 of the Convention for Biological Diversity) which requires that farmlands and forests be managed sustainably to conserve biodiversity (CBD, 2010). On 12th June 1992, Tanzania signed the CBD and ratified it on 1st March 1996. The country has subsequently mainstreamed biodiversity conservation into her sector policies, plans and programs and has continued to implement various measures to ensure sustainable biodiversity conservation. It developed and implemented her first National Biodiversity Strategy and Action Plan (NBSAP) in 2001 (URT, 2001), followed by the NBSAP (2015-2020). The NBSAP was developed in line with the national development vision of 2025 which articulates the need for building a society that values biodiversity richness, using it sustainably and equitably, without jeopardizing the opportunity of future generations to benefit from it. Among others, the specific objectives of NBSAP (2015-2020) are to: 1) ensure sustainable use of biodiversity through strengthened knowledge, awareness raising, support to scientific research and innovations; 2) protect and rehabilitate degraded biomes and threatened species to reduce the rate of habitat loss and genetic erosion; and 
3) promote economic valuation for biodiversity and payments for ecosystem services.

Similar efforts have included the development and implementation of the National Climate Change Strategy (URT, 2012); Strategy on Urgent Actions on Land degradation and Water Catchments (2006); Strategy on Urgent Actions for the Conservation of Marine and Coastal Environment, Lakes, Rivers and Dams (2008); and Development of National Environmental and Action Plan (2013-2018). Other efforts include the development and implementation of the National Strategy for Growth and Poverty Reduction (NSGPR), National Environmental Action Plan (NEAP), National Action Program to Combat Desertification (NAP), National Adaptation Program of Action (NAPA) (URT, 2007), just to mention few.

To combat deforestation and biodiversity loss in fragile agro-ecologies, Tanzania has promoted the implementation of a number of Nature-based Income Generating Activities (NIGAs) supported by various public agencies, NGOs, and international donors. NIGAs have many socioeconomic and conservation benefits. Agroforestry and tree planting, for example, enhances biodiversity through the lessening of pressure of deforestation on additional land and provision of new habitats and resources for local biota and fauna that partly depend on the forest for existence, and could not persist in a more or less exclusive agricultural landscape (Zinngrebe et al., 2020; Sagastuy \& Krause, 2019; Atangana et al., 2014). Beekeeping facilitates the maintenance and promotion of biodiversity and has enormous potential for income generation and sustainable use of forest resources. It supports the diversification of rural livelihoods and the process of artificial pollination for virtually all flowering plants that provide humans with food (Winfree, 2020).

Agroforestry and beekeeping are therefore widely recognized as farming practices which enhance both rural livelihoods and biodiversity conservation (Degu \& Megerssa, 2020). The lack of profit motive is broadly considered as one of the major causes of failure for most of the previous NIGA projects (Tschinkel, 1987; Murray, 1991) but their economic viability is currently poorly documented, at least in the context of developing countries. Most of the previous studies have focused on the physical and biological aspects of NIGAs, neglecting the systematic analysis of their economic contribution at the farm level (Swinkels \& Scherr, 1991). Studies which compare viability between NIGAs and their influence on farmers' adoption are limited (Vergara \& MacDicken, 1990). Where carried out, the analysis was narrowly based on short-term costs and benefits using mostly non-discounted measures of project worth. Hence, some key questions remain, including the interrogation of which NIGAs are more profitable for smallholder farmers, recognizing their economic portfolios? What types of support and policy action are needed to facilitate the adoption of these NIGAs?

To answer these questions, we compare viability of agroforestry and beekeeping at farm level using the case of Uluguru Mountains in Tanzania. The selection of these two NIGAs was informed by the results of farmers' ranking based on the 
potential of individual NIGAs to enhance livelihoods and biodiversity conservation. Agroforestry and beekeeping were ranked as first and second potential NIGAs respectively. Based on the Economic Theory of Entrepreneurship (ETE) developed by Pananek (1962), we considered viability as a crucial incentive for adoption of NIGAs by farmers. Specifically, we evaluated and compared the economic viability of agroforestry and beekeeping projects using the CBA approach.

Our paper is arranged in six sections. The next section (Section 2) presents the theoretical framework for the study, followed by Section 3 which presents the empirical framework. Section 4 describes the study area and methodology. The study findings are presented and discussed in Section 5 and concluding remarks are given in Section 6.

\section{Theoretical Framework}

\subsection{The Economic Theory of Entrepreneurship (ETE)}

Our paper is grounded on the Economic Theory of Entrepreneurship (ETE) which suggests that an entrepreneur executes all activities due to economic incentives. The theory views "profit motive" as the prime driving force that changes an individual into an entrepreneur (Pananek, 1962). The literature on ETE is rich with the mainstream of it considering ownership of capital and ability to supervise the execution of production plan as key prerequisites for ensuring that the project is carried out in an economic manner (Parker, 2018; McFarlane, 2016; Smith \& Chimucheka, 2014; Śledzik, 2013; Kirzner, 1978; Braguinsky et al., 2011; Fernandez, 2009; Langlois, 2002). In the context of agriculture, the ETE would imply an existence of an inner-drive for a rational farmer to decide to practice a certain NIGA rather than its alternative options. This drive can be associated with the perceived economic gains, which make the farmer to allocate his or her available scarce resources into the implementation of a specific NIGA or combination of NIGAs. In fact, the incentives for farmers to practice NIGAs come in different forms, including availability of information and knowledge, affordability of the NIGAs in terms of investment and operating costs, as well as access to extension and lucrative output markets, just to mention few. Thus, policy makers and promoters of NIGAs have to realize these motives which spontaneously develop the readiness of farmers to practice the introduced NIGAs to diversify their incomes and livelihood portfolios. In fact, NIGA programs that consider the characteristics of the target population, and the associated trade-offs between economic, environmental and social outcomes are more likely to be effective than the counterpart programs and initiatives which do not consider (Piñeiro et al., 2020).

\subsection{Cost Benefit Analysis}

Cost Benefit Analysis (CBA) is defined differently by different scholars. David et al. (2013) for example, define CBA as "a systematic approach to estimating the 
strengths and weaknesses of alternatives used to determine options which provide the best approach to achieving benefits while preserving savings; for example, in transactions, activities, and functional business requirements". The analysis helps to gauge if a project or decision is worthwhile undertaking by establishing if and by how much, its benefits outweigh its costs (ibid). The Economic Times (2020) defines CBA as "a procedure for estimating all costs involved and possible profits to be derived from a business opportunity or proposal..." that "takes into account both quantitative and qualitative factors for analysis of the value of money for a particular project or investment opportunity". In this subsection, we survey theories and practices for conducting $\mathrm{CBA}$ and present the procedure for undertaking CBA as summarized in Figure 1.

As shown in Figure 1, the first step entails the identification of existing options, including the status quo or "without" NIGA scenario and the "with" NIGA or promoted scenario. It is important first to gauge the profit of taking up the NIGA investment option instead of continuing with the conventional practices. The second step is to identify and classify costs and benefits and ensure that the effects of each cost and benefit are understood. In the third step, the analyst should sketch the timing of projects or map the activities to be done, indicate when the costs and benefits will occur, and choose the life span or time horizon of the projects in question. It is worth noting here that the choice of time horizon (maximum number of years for which forecasts are provided) requires consistency with the economic life of the main assets in the project as well as, in the general inflation and relative price changes (EC, 2008). It is therefore recommended to establish a point in the future when all the assets and all the liabilities are assumed to be virtually liquidated simultaneously. The choice of appropriate time horizon is important in the determination of the NPV of a project (CREO, 2020).

The fourth step entails the placing of all costs and benefits identified in the previous step in the same monetary numeraire and the fifth steps requires the analyst to make a choice of discount rate that will be used to convert future costs and benefits into present values. A discount rate refers to "a rate of return used to discount future cash flows back to their present value" (Cooperate Finance Institute Website, n.d.). Different discount rates are proposed in the literature. The European Commission, EC (2008) for example, suggests a benchmark real

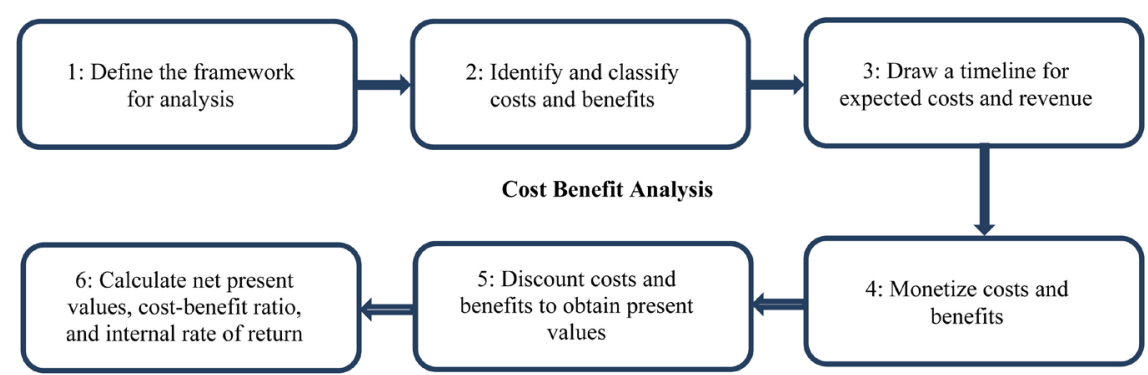

Figure 1. Steps of cost benefit analysis. 
Financial Discount Rate (FDR) of 5\% which is widely accepted as the opportunity cost of capital or sacrificed return on another project or an implicit cost or sink capital invested into a project. In economic analysis, the social discount rate (SDR) is recommended (EC, 2008). SDR mirrors the social perspective on how future benefits and costs are to be valued against the present ones and it can be established using different approaches. One of the key theoretical approaches, for example, requires that the SDR is derived from the predicted long-term growth in the economy (EC, 2008). However, the mainstream literature applauds the Social Time Preference Rate (STPR) approach (Chua \& Choong, 2016; Evans, 2007; Kula, 2006) which is based on the long term rate of growth in the economy, considering the predilection for benefits over time that ponders the anticipation of higher revenue, or consumption, or expenditure. The commonly used formula for estimating STPR from the growth rate is presented in Equation (1):

$$
r=e g+p
$$

where $r$ is the real SDR derived using a proper currency; $g$ is the growth rate of social or government expenditure; $e$ is the elasticity of marginal social welfare with regard to government expenditure, and $p$ is a rate of pure time preference.

The analyst may also reinterpret the STRP formula in terms of consumption with $g$ representing the growth rate of consumption, $e$ being the elasticity of marginal utility with regard to consumption, and $p$ the inter-temporal preference rate (EC, 2008). The first item of the STPR equation is a utilitarian preference and the second one $(p)$ is a pure time preference. It is important to note that all the values in Equation (1) are country specific, especially those of consumption growth $(g)$ which is directly reliant on GDP. Social and private preferences affect the marginal utility parameter $(e)$. Life expectancy and other individual characteristics influence the time preference parameter $(p)$. If income tax structures are assumed to be at least roughly centered on the principle of equal absolute sacrifice of satisfaction, then the extent of progressiveness in the tax structure would provide a metric for $e$ as shown in Equation (2).

$$
e=\log (1-t) / \log (1-T / Y)
$$

where $t$ is the marginal rate of income tax; $T$ is the total income tax liability and $Y$ the total taxable income.

The common approach used to aggregate costs and benefits occurring in different years is by weighting them, using appropriate coefficients, decreasing with time to measure the loss of value of the numeraire. Such a coefficient is called a discounting factor and can arithmetically be expressed as in Equation (3).

$$
a_{t}=(1+r)^{-t}
$$

where $t$ is the time, $r$ is the rate of discount and $a_{t}$ is the coefficient for discounting a value in year $t$ to obtain its present value.

The sixth step is to calculate the NPV, BCR, and IRR which are used as metrics of viability (Fudge, 2011). NPV is calculated as in Equation (4). 


$$
\mathrm{NPV}=\sum_{t=0}^{n}\left(B_{t}-C_{t}\right) /(1+r)^{t}
$$

where; $B_{i}$ and $C_{i}$ represent the total benefits and total costs respectively.

A positive NPV (NPV $>0)$ implies that the project yields a net benefit because the sum of the weighted flows of costs and benefits is positive, and therefore generally desirable. BCR is the present value of project benefits divided by the present value of project costs and is calculated as shown in Equation (5).

$$
\mathrm{BCR}=\sum_{t=0}^{n}\left(\left(B_{t}\right) /(1+r)^{t}\right) / \sum_{t=0}^{n}\left(\left(C_{t}\right) /(1+r)^{t}\right)
$$

If $\mathrm{BCR}>1$ the project is worth undertaking because the benefits, measured by the Present Value of the total inflows, are greater than the costs, measured by the Present Value of the total outflows. IRR is defined as the discount rate that zeroes out the NPV of flows of costs and benefits of an investment (Florio et al., 1997). It is the discount rate at which it would be just worthwhile doing the project. So the IRR is the discount rate, $r^{*}$, at which:

$$
\mathrm{BCR}=\sum_{t=0}^{n}\left(\left(B_{t}-C_{t}\right) /(1+r)^{t}\right)=0
$$

The arithmetic rule of calculating IRR requires the use of two discount rates: one which gives a positive NPV and the other which gives a negative NPV as presented in Equation (7).

$$
\mathrm{IRR}=r_{1}+\left[\left(r_{1}+r_{2}\right)\left(\mathrm{NPV}_{1} / \mathrm{NPV}_{1}-\mathrm{NPV}_{2}\right)\right]
$$

where; $r_{1}$ is the lower discount rate, $r_{2}$ is the higher discount rate, $\mathrm{NPV}_{1}$ is the $\mathrm{NPV}$ at the lower discount rate, and $\mathrm{NPV}_{2}$ is the NPV at the higher discount rate.

\section{Empirical Framework}

The analysis and comparison of viability of Good Agricultural Practices (GAPs) have recently received attention among scholars (Ahmed \& Sallam, 2020; Adhikari et al., 2019; Jenkins et al., 2018; Lazaro et al., 2017; Daujanov et al., 2016). In the Upper Egypt for example, Ahmed \& Sallam (2020) assessed the potential for improving the livelihoods of rural communities from proposed agricultural interventions. They conducted a CBA and risk analysis using the Monte Carlo simulation method. Specifically, they evaluated agricultural interventions that convert the existing traditional farming and marketing practices to modern export or high-end market-oriented production of fresh horticultural export crops (i.e. table grapes, green beans, and green onions) via the improved use of market intelligence and logistics. They found the proposed interventions to be viable from both financial and socio-economic perspectives having low risk and probability of yielding negative returns. In Nepal, Adhikari et al. (2019) conducted a CBA to compare categories of farming households (i.e. farmers using improved seed and farmers using local seed for maize production). They assessed viability using undiscounted BCR or the benefit per unit cost. 
In Nigeria, Jenkins et al. (2018) conducted CBA of a series of agriculture production and productivity enhancing interventions in the cowpea, groundnuts, maize, and soybean value chains. Specifically, they assessed the financial and economic benefits of adopting best agricultural practices in growing these crops using an Integrated Investment Appraisal (IIA) method. They define IIA as a method of CBA that measures benefits and costs in financial and economic terms making it possible to identify, quantify and allocate costs and benefits to the appropriate parties. Their analysis covered a 10-year period from 2015 to 2025, comparing the "with-project" and "without-project" scenarios using the real financial and economic discount rates of $12 \%$. Their model first derived nominal cash flows, which were then discounted according to price indexes (World Bank inflation and exchange rate data). Their findings indicate that the interventions improved households' incomes across all value chains. Conversely, they argue that assistance alone for growing crops would not necessarily help the farmers to move out of poverty. Farmers needed to diversify their sources of income by undertaking other economic activities such as livestock husbandry and off-farm sources.

Daujanov et al. (2016) used a hypothetical situation to conduct CBA where the farm decides to switch from conventional agriculture to conservation agriculture (CA). Their study assumed a farm of 50 ha having all the necessary machinery for conventional agriculture, except a harvesting combine which is rented from the government or private companies. They assumed a cotton-winter wheat-maize rotation and a CA based on tillage and that no crop residue left on the field. The CA practices included planting on permanent beds, permanent soil cover and crop rotation. They used an SDR of $4.67 \%$ which was considered to be equal to the marginal rate of return on private investments, adjusted for inflationary expectations. To calculate the SDR, they used the Uzbekistan interest rate on bank deposits of 12\% and inflation rate of 7\% in 2014 . Their results suggested that the investment in CA implementation would result in positive incremental benefits if the advantages of CA were monetized. Their results also indicated that even if the net incremental benefits in a crop rotation cycle were positive, the same was not adequate to recover the investment expenses in the long-term period. However, the use of a hypothetical situation and the assumption of a farm size of 50ha ignore the realities of smallholder farming systems in mountain areas, such as that of the Eastern Arc Mountains (EAMs) in East Africa where land is often scarce and concerns about loss of biodiversity are rampant.

Most imperative here is the fact that CBA studies comparing long-term economic viability of NIGAs introduced in agro-ecologies of tropical mountainous areas are generally rare. Where available, they mostly focus on individual agricultural value chains (e.g., Adhikari et al., 2019; Jenkins et al., 2018) or single practice, like agroforestry (Wainaina et al., 2020; Van Thang et al., 2015; Rahman et al., 2007; Current et al., 1995) or single technology, like climate-smart agriculture (Sain et al., 2017). Studies which compare viability between different 
mountainous NIGAs are lacking.

Many studies have also applied undiscounted approaches to CBA, like the gross margin and short-term benefit per unit cost approaches (e.g., Adhikari et al., 2019; Kuboja et al., 2017; Lazaro et al., 2017) disregarding the potential disparities in the value of money for long-term projects (the value of money today is not the same as the value of same money tomorrow). Lazaro et al. (2017) for example, used the gross margin approach to measure viability of GAPs in an Integrated Maize-based Farming System. They found profit from these GAPs to be not statistically different from that of the conventional practice, at least in the short time duration. However, the reliance on undiscounted short-term measures may undermine the actual long-term viability and lead to indecisive policy recommendation and formulation.

In fact, there are many aspects of NIGAs which remain not well known by researches, government and development partners promoting them. For example, it is not known with certainty why farmers can appreciate the potential of an introduced NIGA as a livelihood and biodiversity enhancing strategy but they do not practice it. In the Uluguru Mountains for example, beekeeping was ranked as the second important NIGA but it was adopted by only very few farmers $(8.4 \%)$. It is therefore important to investigate these aspects to inform current and future policies and initiatives for sustainable livelihoods and biodiversity conservation. Our study investigated the viability of agroforestry and beekeeping in the long-term period. We discounted the streams of costs and benefits using a time horizon of 10 years and different interest rates to estimate and compare the respective NPVs and BCRs of the two projects. Where the data were not readily available or not reliable we complemented the analysis with information and data transferred from similar studies conducted elsewhere in Tanzania. In this regard, the study by Kuboja et al. (2017) provided very useful price information and data, especially for the CBA of beekeeping project though their study also did not use discounted values.

\section{Study Area and Methodology}

\subsection{Study Area}

The study was conducted in fourteen hamlets located near or along the Uluguru Mountains Nature Reserve (UMNR) in the wards of Mlimani and Luhungo (Morogoro Municipality), and Mzumbe (Mvomero district). Located at altitudes of between 650 and 1400 meters above sea level (Figure 2), the study sites are mountain areas. Geologists classify a mountain as a landform that rises at least 300 meters or more above its surrounding (National Geographic Website, n.d.). Though harbor many endemic flora and fauna species, mountain areas are generally vulnerable to many natural and anthropogenic threats, including frequent fires, land cover change and agricultural intensification, just to mention few (Secretariat of the Convention on Biological Diversity, n.d.).

As in many other mountain areas, forest resources in the study area are threatened by uphill expansion of agriculture and human settlements, logging 


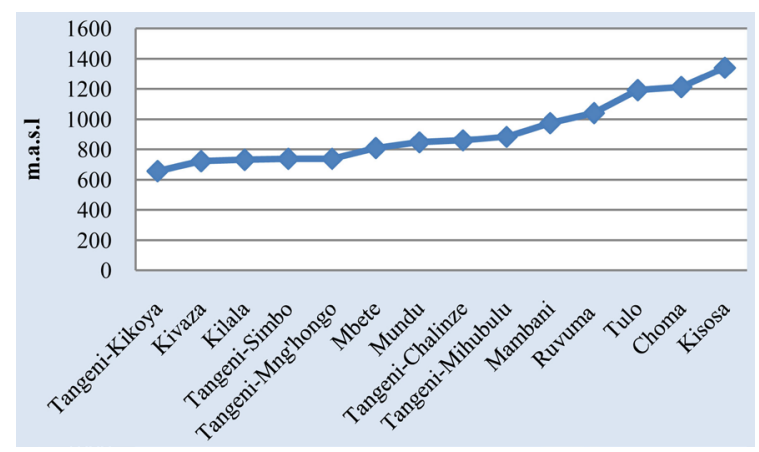

Figure 2. Altitudinal locations of the study hamlets.

for timber and fuel wood. As such, there are different land uses in the area (Figure 3), especially in the hamlets that border the Uluguru Mountains Forest Reserve which constitute a biodiversity hotspot and home to hundreds of species found nowhere else on earth. The area also serves as a water catchment and water source for populations living downstream in Morogoro rural and Municipality as well as other residents in the Dar es Salaam City and the Ruvu/Wami River Catchments. Land degradation in the study area is reported to be rampant caused by unsustainable anthropologic activities (Massawe et al., 2020; Massawe et al., 2019; Harrison \& Mdee, 2017; William, 2010; Yanda \& Munishi, 2007; Lyamuya et al., 1994).

\subsection{Methodology}

\subsubsection{Sampling and Data Collection}

We used the multi-stage sampling procedure to select the study villages and sample households. In the first stage, fourteen hamlets were selected purposely based on their participation in the previous NIGA projects, notably the Uluguru Mountains Payment for Watershed Services Project (UMPWSP), funded by the Department for International Development Civil Society Challenge and supported by the Royal Society for the Protection of Birds (RSPB) in partnership with the Wildlife Conservation Society of Tanzania (WCST) and others.

In the second stage, households were stratified into strata according to wealth ranks assigned previously by UMPWSP. The third stage entailed the selection of sample households from each stratum using the proportionate probability sampling procedure. This led to a total of 201 sample households though the number dropped down to 154 households after data cleaning and removal of outliers. The distribution of sample by study site is shown in Figure 4 .

The study used both primary and secondary data. Prior to commencement of fieldwork, we hired six enumerators to assist in data collection. These were trained on how to administer questionnaires and use other research tools (checklists and guidelines). They were also reminded about the research ethics they should comply with.

The actual fieldwork started with a reconnaissance survey to get an overview and understanding of the study area and applicability of the questionnaire. 


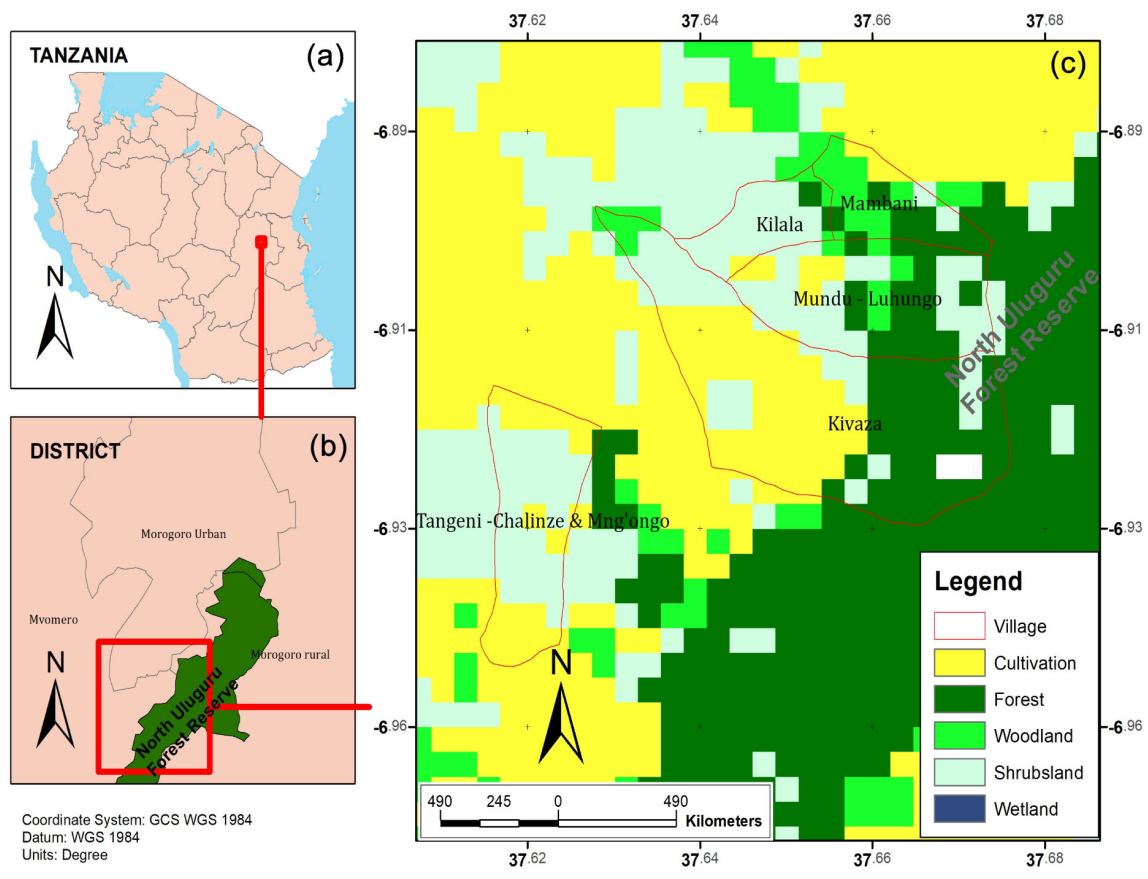

Figure 3. Map showing the location of the study sites and existing land uses.

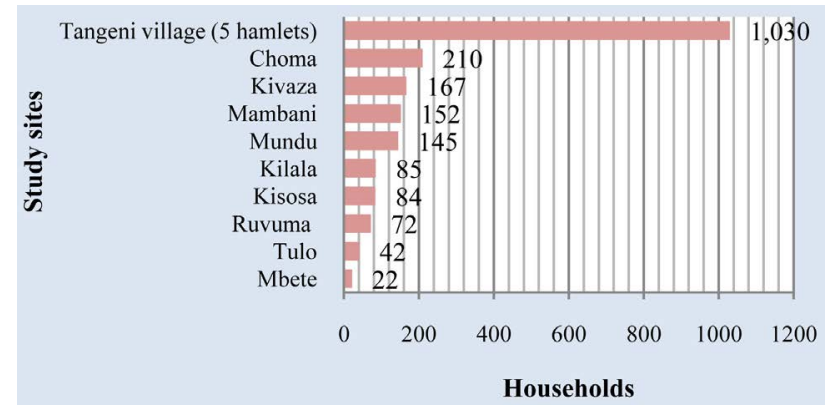

(a)

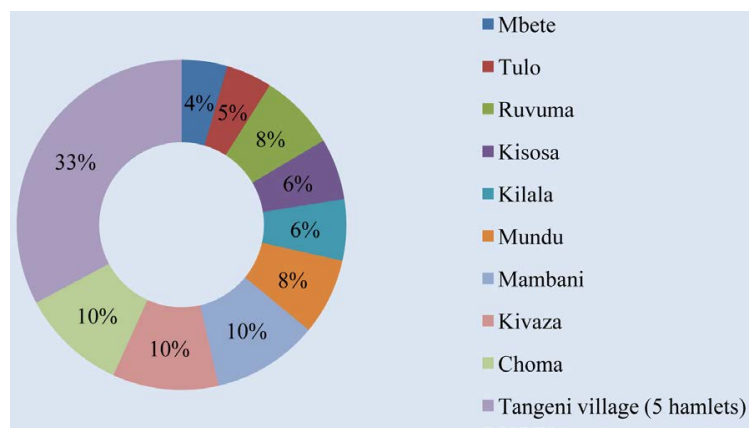

(b)

Figure 4. Total households and proportion of sample households in the study sites. (a) Total households in all the study sites = 2009; (b) Proportion of sample households $(\mathrm{N}=$ 201).

During the reconnaissance survey the household questionnaire was pre-tested to a small number of respondents before the actual survey to check for its relevance to the study area and objectives. This was followed by the main survey which 
used different research tools and techniques, including structured questionnaires, key informant interviews (with interviewees selected based on their involvement in NIGA initiatives) and Focus Group Discussions (FGDs). The FGDs were attended by about 10 participants per hamlet representing different socioeconomic groups that existed in the area, including the rich, poor, youth and women, men, abled and disabled people. In addition, direct observation served as a complementary tool. In selecting the key informants for interview, the snowball technique was used. The technique is particularly suitable when the population of interest is hard to reach and compiling a list of the population poses difficulties for the researcher (Etikan et al., 2016). It begins with a convenience number of initial subject which serves as "seeds," through which wave 1 subject is identified; wave 1 subject, in turn, identifies wave 2 subjects; and the number of interviewees consequently expands wave by wave-like a snowball growing in size as it rolls down a hill (Heckathorn, 2015).

\subsubsection{Data Processing and Analysis}

The analysis and comparison of economic viability of agroforestry versus beekeeping benefited from the information and data gathered during FGDs, KII and questionnaire survey, complemented by information gathered through the deskwork review of relevant documents. The information and data gathered during the fieldwork and through literature review helped the generation of streams of costs and benefits of the two NIGAs over the life span or time horizon of 10 years. Both the short and long term costs and benefits were taken into consideration to ensure that the projections are based on realistic lifespan of the respective NIGAs, looking at how both costs and benefits evolve over time. The identification of physical amounts and expected value of costs and benefits (i.e. the financial receipts and outlays as measured by market prices) entailed the specification of when they occur in time.

The types of benefit and cost information gathered included: 1) the direct benefits and costs associated with the production of a cost object, like product, service, or activity; 2) indirect benefits and costs, which are usually fixed in nature, and may come from overhead of the NIGAs; 3) tangible benefits and costs, which usually related to an identifiable source or asset, like purchasing tools; and 4) real benefits and costs or expenses associated with producing an offering (product or service).

Moreover, information and data on interest rates were gathered to inform the selection of discount rate for future benefits and costs to obtain the present value (the equivalent value that one is receiving or giving up today when the decision to adopt a certain NIGA is made). NPV, in this case, refers to the present value of the NIGA's net benefit stream, obtained by discounting the stream of net benefits produced by the NIGA over its lifetime, back to its value in the chosen base period, usually the present. The market rate of interest and social interest rate (SDR) were used for discounting the annual net-benefit stream of NIGAs. Recognizing the difference in lives of assets between agroforestry and beekeeping 
projects, we constructed a scenario to maintain consistency in the time horizons of the two projects. The economic life of most assets in beekeeping (e.g. beehives) is often around 10 years whereas an agroforestry project is often complex requiring enduring capital due to large up-front capital demands and relatively longer time horizons spent to grow trees (CREO, 2020; Do et al., 2020). In our study, we used the same time horizon (10 years) for CBA in Agroforestry and beekeeping and established the mean current value of agroforestry land operated by farmers and used it as a proxy of investment cost. This makes sense because one may decide to invest in an already existing agroforestry project instead of investing in a new one.

The investment in the existing agroforestry was valued using the Contingent Valuation Method (CVM). Derived from neoclassical welfare economics, CVM is a stated preference approach which "explores the fundamental concept of utility as reflected in both use and non-use values and measured by the metrics of maximum Willingness to Pay (WTP) and minimum Willingness To Accept Compensation (WTAC)" (Hanley, 2002). It is theoretically sound because the method (CVM) explicitly incorporates respondents' values via the level of WTP or WTAC they specify. Since our study interrogated owners and operators of agroforestry land it was deemed appropriate to use the WTAC approach rather than WTP as the latter approach would be appropriate when interviewing potential buyers. We then obtained mean values of investment and operating costs as well as annual revenues which enabled us to prepare and make projection of costs and benefit streams as well as the computation of NPVs and BCRs. NPVs, BCRs and IRR were used as key metrics of economic viability in this study. Table 1 presents the key parameters and assumptions we used to carry out our CBA in agroforestry.

For beekeeping project, we used the unit cost of investment per beehive established from Key Informant Interviews (KIIs) conducted in the study sites because farmers who practiced beekeeping were relatively few $(8.4 \%)$ to justify a realistic statistical analysis based on primary data generated from the questionnaire survey. We generated the costs and benefits streams of beekeeping using the Benefit Transfer (BT) method to collate secondary data and information from previous studies, notably the study by Kuboja et al. (2017). Benefit transfer is a procedure for taking the estimates of economic benefits (or values in general) gathered from one site and applying them to another (Plummer, 2009). In this

Table 1. Key assumptions used in the valuation of economic viability of agroforestry project.

\begin{tabular}{cc}
\hline Parameter & Value \\
\hline Project lifespan & 10 \\
Investment cost (WTAC/acre) (TZS) & $2,298,944.57$ \\
Operating costs/acre/year (TZS) & $107,810.42$ \\
Revenue/acre/year & $463,030.37$ \\
\hline
\end{tabular}


study we used a common method that applies an estimate of value per acre assuming similar land-cover or habitat type. It should however be noted that BT is rarely the best choice for analyzing the economic values of a project, but the costs of gathering primary, site-specific data have made it a common practice for studies that use natural sites (Plummer, 2009; Rosenberger \& Loomis, 2001). The detailed discussions of the theoretical and informational requirements for $\mathrm{BT}$, as well as the steps required to implement it, are provided in Johnston et al. (2015).

The key assumptions and respective sources of information in viability analysis of the beekeeping project are given in Table 2. For information and data sourced from previous studies (notably Kuboja et al., 2017 in this study) the major assumption was that prices have not changed significantly between 2017 and 2020 .

We then discounted the streams of benefits and costs using a discount rate of $3.2 \%$, which was the current rate of inflation in Tanzania during the time of data collection. According to the recent report by the Bank of Tanzania, BoT (2020) this rate has almost remained constant, recording a twelve-month headline inflation of 3.3\% in April 2020. CBA was repeated using different discount rates $(1 \%, 2 \%, 4 \%, 5 \%, 6 \%, 7 \%, 8 \%, 9 \%, 10 \%, 15 \%$, and $20 \%)$, primarily as part of sensitivity analysis to test the robustness of the CBA results to changes in inflation or interest rates.

\section{Results and Discussion}

\subsection{Adoption of Agroforestry and Beekeeping}

The respondents in our study ranked agroforestry and beekeeping as the first and second NIGAs that have the potential to enhance livelihoods and biodiversity conservation. The common agroforestry systems in the study area were homegardens (about 72\%), where several crops are grown mainly for commercial purposes, including banana and different tree varieties, such as the jackfruit, mango, cinnamon, cardamom, breadfruit, coco palm and eucalyptus, as well as, the hillside agroforestry systems (approximately 28\%) where food crops like

Table 2. Key assumptions used in the valuation of economic viability of beekeeping project.

\begin{tabular}{lc}
\hline \multicolumn{1}{c}{ Item } & Value \\
\hline Unit cost of investment per beehive in TZS (own field survey) & $130,000.00$ \\
Total cost of beehives investment in TZS (own field survey) & $1,430,000.00$ \\
Household members full involved in beekeeping (Kuboja et al., 2017) & 11 \\
Total number of beehives harvested (ibid) & $13,893.00$ \\
Labor cost per beehive in TZS (ibid) & $10,137.00$ \\
Transport cost per beehive in TZS (ibid) & $41,451.00$ \\
Actual profit per beehive (ibid)
\end{tabular}


maize and cassava, mixed with yams and common beans, dominate with relatively fewer scattered trees and shrubs. Beekeeping entailed mostly the use "tree apiaries" whereby the hives were suspended from tall shade trees so that bystanders, like domestic animals and people are safe from bee stings. Relatively however, beekeeing was practised by only few farmers (8.4\%) compared to agroforestry which was practiced by more farmers (72.1\%) than (Figure 5).

The causes of low rate of adoption of beekeeping were rigorously discussed during the FGDs and KIIs conducted in the study area. The participants attributed it largely to the lack of suitable land at the proximity of farmer's homestead, inadequate access to extension services and lack of capital. The lack of land suitable for setting up the apiary and ensuring its safety was also reported by Tutuba \& Vanhaverbeke (2018) as discouraging farmers to practice beekeeping in Mvomero District, Tanzania. The shortage of land is particularly important in mountain areas where population density is often high (de la Masselière et al., 2017; EAC/UNEP/GRID-Arendal, 2016). Our results of analysis of landholdings in the study area for example indicate that on average, agroforestry farmers operated about 1.5 acres which were slightly smaller than the mean of 1.8 acres for monoculture cropping. Approximately $32 \%$ of the total farmland was located at a distance of more than a kilometer from homestead. Yet, the possession of adequate and suitable land for beekeeping cannot be generalized as a major limitation because evidence from elsewhere in the District Panchkula (Haryana), India indicates that landless farmers can install their beekeeping units on the farm of others (Monga \& Manocha, 2011).

Access to adequate technical assistance and extension services was also emphasized as central to ensuring sustainable and profitable agroforestry and beekeeping. In beekeeping for example, farmers require knowledge and skills in appropriate queen rearing, colony division, apiary management, beehive product harvesting, processing, and honey handling (Tutuba \& Vanhaverbeke, 2018). The lack of appropriate knowledge and skills causes inefficiencies, poor occupancy rates, and poor beekeeping quality products. Famers should be helped to

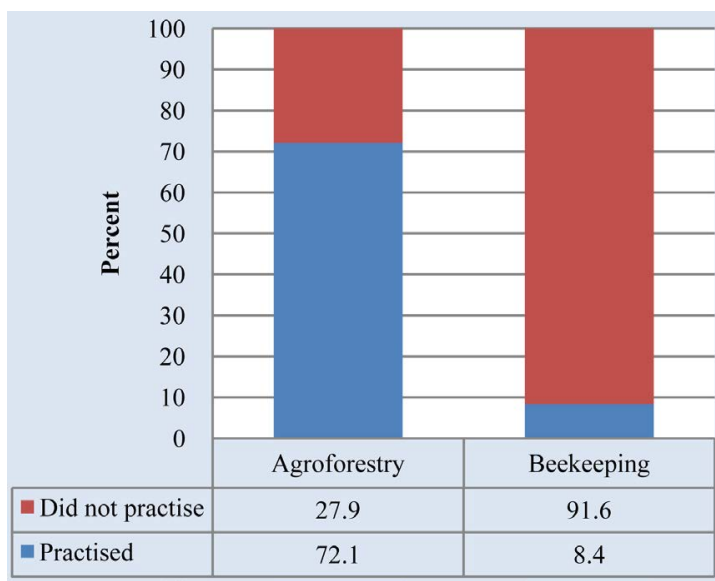

Figure 5. Proportion of farmers who practiced agroforestry and beekeeping versus those who did not practice (\%). 
own modern beehives and improve the productivity and quality of beehive products through effective extension services and technical supports (Piñeiro et al., 2020; Adhikari et al., 2019; Mujuni et al., 2012). They should be enabled to work within a high-quality beekeeping value chain so that they can become more productive and profitable.

The information we gathered from FGDs and KIIs also indicated that most farmers were willing to invest in beekeeping, but they were limited by their financial means and access to capital for beekeeping investment. Beekeeping was also constrained by access to quality beekeeping inputs, including the modern or commercial hives, as well as, the harvesting and processing tools or equipment. Where available, these inputs were viewed to be too expensive for smallholder farmers to afford purchasing them. Farmers who practiced agroforestry incurred relatively higher costs than their counterpart farmers who did not practice it (Figure 6).

\subsection{Results of Viability Analysis for Agroforestry and Beekeeping}

Our results of $\mathrm{CBA}$ indicate that both the agroforestry and beekeeping projects were viable at the discount rate equal to the inflation rate (i.e., $r=3.2 \%$ ) with NPVs of TZS 700,459.40 and TZS 188,092.63 per acre respectively. In fact, the two projects were viable even at a higher discount rate of $8 \%$ yielding NPVs of TZS 84,610.21 and TZS 82,479.98 per acre respectively. For agroforestry, the BCRs at discount rates of $3.2 \%$ and $8 \%$ were 1.22 and 1.14 respectively. The BCRs for beekeeping at discount rates of $3.2 \%$ and $8 \%$ were 1.05 and 1.03 for beekeeping, respectively. Overall, the results of comparison of economic viability between agroforestry and beekeeping projects indicated that the former (agroforestry) was more profitable than the later (beekeeping) at discount rates equal or less than $8.2 \%$ and $8.5 \%$ respectively in terms of both NPVs and BCRs (Table 3 ).

Table 3. Comparison of economic viability between agroforestry and beekeeping projects. (a) Agroforestry; (b) Beekeeping.

(a)

\begin{tabular}{|c|c|c|c|c|c|c|c|c|c|c|}
\hline \multirow{2}{*}{ Measure $^{\star}$} & \multicolumn{10}{|c|}{ Discount rate } \\
\hline & $3.2 \%$ & $4 \%$ & $5 \%$ & $6 \%$ & $7 \%$ & $8 \%$ & $9 \%$ & $10 \%$ & $15 \%$ & $20 \%$ \\
\hline PVB & $3,909,732.92$ & $3,755,591.07$ & $3,575,397.78$ & $3,407,943.83$ & $3,252,131.56$ & $3,106,971.47$ & $2,971,570.42$ & $2,845,121.18$ & $2,323,842.29$ & $1,941,241.90$ \\
\hline PVC & $3,209,273.51$ & $3,173,383.65$ & $3,131,428.06$ & $3,092,438.65$ & $3,056,159.85$ & $3,022,361.26$ & $2,990,834.94$ & $42,961,392.93$ & $2,840,020.12$ & $2,750,936.75$ \\
\hline NPV & $700,459.40$ & $582,207.42$ & $443,969.73$ & $315,505.18$ & $195,971.71$ & $84,610.21$ & $-19,264.52$ & $-116,271.75$ & $-516,177.83$ & $-809,694.85$ \\
\hline BCR & 1.22 & 1.18 & 1.14 & 1.1 & 1.06 & 1.03 & 0.99 & 0.96 & 0.82 & 0.71 \\
\hline
\end{tabular}

(b)

\begin{tabular}{|c|c|c|c|c|c|c|c|c|c|c|}
\hline \multirow{2}{*}{ Measure $^{*}$} & \multicolumn{10}{|c|}{ Discount rate } \\
\hline & $3.2 \%$ & $4 \%$ & $5 \%$ & $6 \%$ & $7 \%$ & $8 \%$ & $9 \%$ & $10 \%$ & $15 \%$ & $20 \%$ \\
\hline PVB & $3,850,040.61$ & $3,698,252.15$ & $3,520,809.98$ & $3,355,912.65$ & $3,202,479.26$ & $3,059,535.42$ & $2,926,201.62$ & $2,801,682.96$ & $2,288,362.76$ & $1,911,603.76$ \\
\hline PVC & $3,413,756.40$ & $3,329,565.14$ & $3,231,331.09$ & $3,140,239.05$ & $3,055,667.25$ & $2,977,055.45$ & $2,903,898.19$ & $2,835,738.88$ & $2,556,739.66$ & $2,354,633.65$ \\
\hline NPV & $436,284.22$ & $368,687.01$ & $289,478.89$ & $215,673.6$ & $146,812.01$ & $82,479.98$ & $22,303.44$ & $-34,055.92$ & $-268,376.89$ & $-443,029.88$ \\
\hline BCR & 1.13 & 1.11 & 1.09 & 1.07 & 1.05 & 1.03 & 1.01 & 0.99 & 0.9 & 0.81 \\
\hline
\end{tabular}

${ }^{*}$ Currency $=$ Tanzanian Shilling (TZS). 


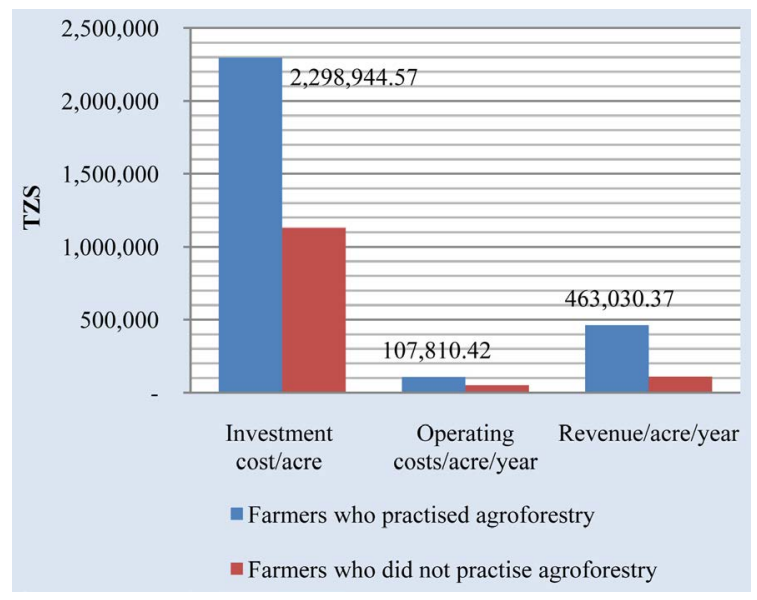

Figure 6. A comparison of average costs and benefits between farmers who practiced agroforestry and those who did not practice it.

The NPVs were negative at discount rates higher than $8.2 \%$ and $8.5 \%$ for agroforestry and beekeeping respectively implying that the projects were not viable beyond these rates. However, it is important to note that these two cut-off rates embrace the SDR of 5\% recommended by EC (2008), as well as the mean savings deposit rates for Tanzania (i.e., $2.46 \%$ and $2.3 \%$ which were reported by the National Bank of Tanzania in April 2019 and March 2020 respectively) (Bank of Tanzania, BoT, 2020). This suggests that farmers in the study areas were relatively better off investing their money in agroforestry and/or beekeeping than depositing it in the banks. The two cut-off discount rates of $8.2 \%$ and $8.5 \%$ for agroforestry and beekeeping can also be compared with the country's growth rate in real GDP of $7.2 \%$ in $2016-2017$, and $7.0 \%$ in 2018 , as well as, the interest rates offered on deposits, which averaged at $7.04 \%$ and $6.69 \%$ in April 2020 and April 2019, respectively (BoT, 2020). The 12-month deposit rates averaged at $7.93 \%$ and $8.01 \%$ in 2019 and 2020 respectively (ibid).

Using the SDR recommended by EC (2008), that is 5\%, the NPVs for agroforestry and beekeeping amounted to TZS 444,969.73 and TZS 289,478.89 per acre with BCRs of 1.14 and 1.07 respectively (Table 3). Again, this indicates that the two projects were not only economically viable but also socially justifiable. The NPVs at discount rate of 7\% (which is closely equal to the country's growth rate in real GDP) were TZS 195,971.71 and 146,812.01 per acre for agroforestry and beekeeping respectively. The BCRs were 1.06 and 1.05 respectively. In sense, our original choice of discount rate that equals the inflation rate (3.2\%) was pretty reasonable for a number of reasons: firstly, lower discount rates are more preferable when analyzing viability of projects that affect future generation (Arrow et al., 2013). At the time of survey, the country's inflation rate was relatively lower than most of the economic indicators and rates presented in the previous paragraph. Secondly, the rate $3.2 \%$ is not only economically sound but also socially justifiable at least in the perspective of Irving Fisher who called interest as "an index of a community's preference for a dollar of present [income] over a 
dollar of future income". Fisher (1930) dubbed his theory of interest as the "impatience and opportunity" theory. He theorized results from the interaction of two forces: the "time preference" individuals have for capital now, and the investment opportunity principle (that income invested now will yield greater income in the future). This proposition tortuously advocates the use of "rate of return on investment" as an appropriate discount rate. However, this works well when there are no market imperfections and distortions and the consumption rate of discount can then be considered as equal to the rate of return on investment.

Thirdly, our discount rate of choice (3.2\%) was also close to the constant rate of $3 \%$ which was recommended by OMB (2003) for estimating the consumption rate of discount when evaluating projects that involve intragenerational benefits and costs. However, this requires the analyst to comply with the two-step estimation procedure by firstly using a constant rate of $3 \%$ to estimate the consumption rate of discount and, secondly by separately using a discount rate of 7\% (the real, before-tax average return on private investment). For projects with important intergenerational benefits and costs, an additional lower but positive discount rate can be used (Arrow et al., 2013; OMB, 2003).

In addition to comparing the economic values using the yardsticks of NPV and BCR we also compared the efficiency between the two projects (agroforestry and beekeeping projects) using IRR. In principle, the IRR decision rule can be applied when the sign of net benefits (benefits minus costs), does not vary in the different years of the project. The rule ceases to offer useful information as a metric of project worthiness when the sign of net benefits changes between various years of the project lifespan (Lanctot, 2019; EC, 2008; Ley, 2007). This can easily be verified by plotting the NPVs against different discount rates to see if there are several rates which equate NPV to zero. In this regard, we plotted the NPVs against various discount rates starting from $1 \%$ to $20 \%$ and both projects yielded single IRRs (see Figure 7 and Figure 8 for agroforestry and beekeeping projects respectively).

In principle, an investment is considered acceptable if its IRR is greater than an established minimum acceptable rate of return, which in our case was either

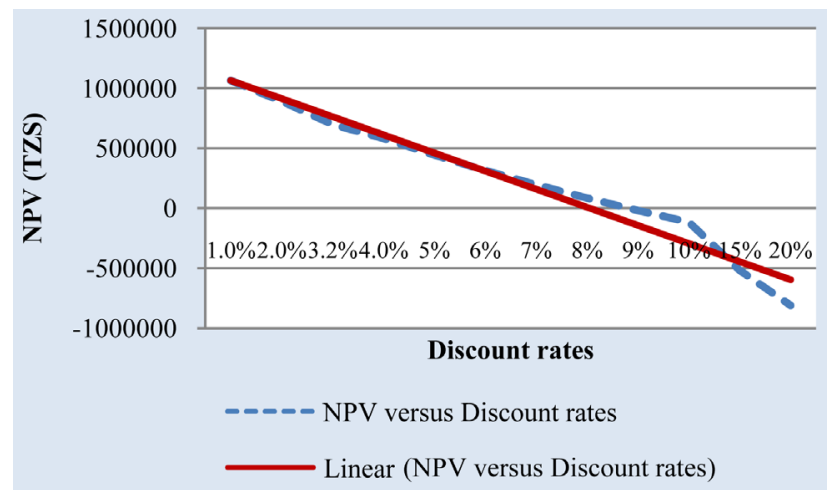

Figure 7. A line plot of NPVs of agroforestry at different discount rates. 


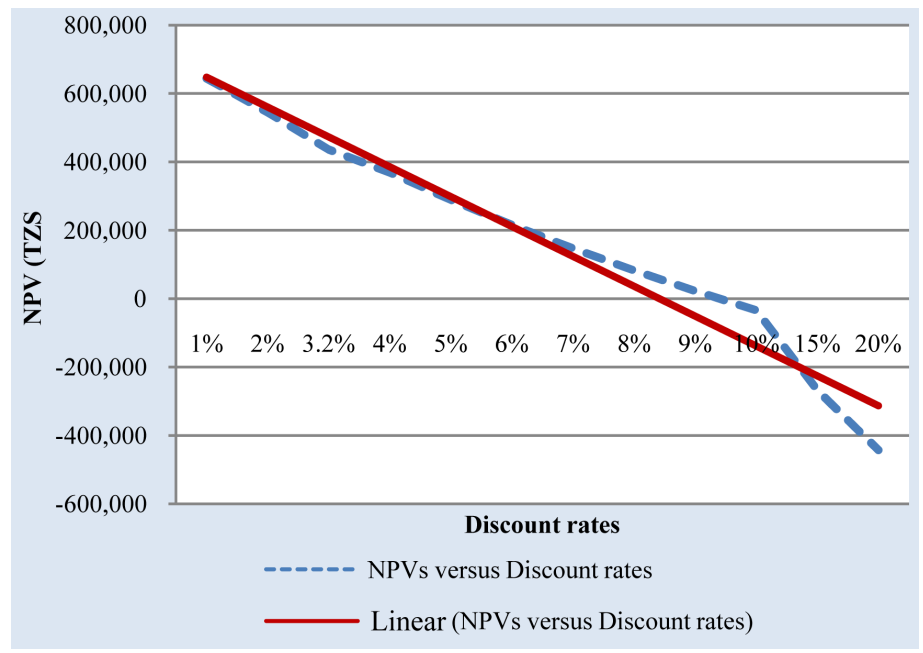

Figure 8. A line plot of NPVs of beekeeping at different discount rates.

the inflation rate of $3.2 \%$ or SDR of $5 \%$. In this regard, both agroforestry and beekeeping projects were worthy undertaking though our mathematical and graphical extrapolations of IRR indicated that beekeeping was slightly more efficient $(\mathrm{IRR}=8.5 \%)$ than agroforestry $(\mathrm{IRR}=8.2 \%)$. However, as we have just indicated in the foregoing paragraphs the NPV and BCR of agroforestry were higher than that of beekeeping project. In fact, NPV is often considered as a much more reliable measure of project viability than IRR and a most preferable criterion when ranking investments and projects which are mutually exclusive (Cooperate Finance Institute Website, n.d.). Yet, farmers could benefit more by practicing both (i.e. beekeeping as part of agroforestry) but investment was limited by the availability of funds and/or by the famer's ability to manage a more diversified pattern of NIGAs.

\section{Conclusion}

A study was conducted to evaluate and compare the economic viability of agroforestry and beekeeping in the Uluguru Mountains in Tanzania using a discounted measure of costs and benefits (CBA). The results of analysis yielded positive NPVs for both agroforestry and beekeeping projects at discount rates not higher that $8.2 \%$ and $8.5 \%$ respectively. Measured in terms of IRR however, beekeeping was slightly more efficient than agroforestry. Overall, the results of comparison of economic viability between agroforestry and beekeeping projects revealed that the former was more profitable than the later in terms of both the NPV and BCR criteria. Yet, we underscore the fact that these two projects can jointly be implemented to enhance farmers' livelihoods and support biodiversity in agro-ecologies similar to that of Uluguru Mountains. However, farmers need to be supported by the government and other development partners in terms of training and inspiration to shift from orthodox farming to sustainable NIGAs, such as, agroforestry and beekeeping. We recommend future viability studies to use a combination of empirical models and judgment to predict future discount 
rates and evaluate correlation of results. This is important because future discount rates are inherently uncertain due to uncertainty in the rates of growth in consumption and returns to investment.

\section{Acknowledgements}

This paper is based on a postgraduate research conducted under the Department of Forest and Environmental Economics of the Sokoine University of Agriculture (SUA) in Tanzania. The authors would therefore wish to extend their sincere gratitude to the former and current heads of the Department of Forest and Environmental Economics at SUA, Prof. Jumanne Abdallah and Dr. Greyson Z. Nyamoga respectively, as well as the academic staff of the Department for their enormous academic support. Our sincere acknowledgements are also due to $\mathrm{Mr}$. Raymond R. Kilenga, the Programme Officer of the Eastern Arc Mountains Conservation Endowment Fund; Ms. Bernadetha Chille, the Principle Forest Officer of the Uluguru Forest Nature Reserve; the respondents and village/hamlet leaders in the study area for their hands of support as well as excellent cooperation and inputs during the fieldwork.

\section{Conflicts of Interest}

The authors declare that they have no conflicts of interest.

\section{References}

Adhikari, S., Dahal, B. R., \& Bist, V. (2019). Technology Adoption in Maize Farming: A Comparative Analysis between Improved Seed Users and Local Seed Users of Argakachi District of Nepal. Agricultural Science and Technology, 11, 332-337. https://doi.org/10.15547/ast.2019.04.056

Ahmed, O., \& Sallam, W. (2020). Assessing the Potential of Improving Livelihoods and Creating Sustainable Socio-Economic Circumstances for Rural Communities in Upper Egypt. Sustainability, 12, 6307. https://doi.org/10.3390/su12166307

Alroy, J. (2017). Effects of Habitat Disturbance on Tropical Forest Biodiversity. Proceedings of the National Academy of Sciences of the United States of America, 114, 6056-6061. https://doi.org/10.1073/pnas.1611855114

Arrow, K., Cropper, M., Gollier, C., Groom, B., Heal, G., Newell, R., Nordhaus, W., Pindyck, R., Pizer, W., Portney, P., Sterner, T., Tol, R. S. J., \& Weitzman, M. (2013). Determining Benefits and Costs for Future Generations. Science, 341, 349-350. https://doi.org/10.1126/science.1235665

Atangana, A., Khasa, D., Chang, S., \& Degrande, A. (2014). Agroforestry and Biodiversity Conservation in Tropical Landscapes, In Tropical Agroforestry (pp. 227-232). Dordrecht: Springer. https://link.springer.com/chapter/10.1007/978-94-007-7723-1_11 https://doi.org/10.1007/978-94-007-7723-1_11

Bank of Tanzania, BoT (2020). Monthly Economic Review. https://www.bot.go.tz/Publications/Regular/Monthly\%20Economic\%20Review/en/202 0061913292779.pdf

Braguinsky, S., Klepper, S., \& Ohyama, A. (2011). Schumpeterian Entrepreneurship. SSRN Electronic Journal, 1-35. https://doi.org/10.2139/ssrn.1347063

CBD (2010). Decision X/2_Strategic Plan for Biodiversity 2011-2020. In Conference of 
the Parties. Nagoya: The Convention for Biological Diversity. https://www.cbd.int/sp/elements

Chua, A., \& Choong, W. W. (2016). A Review of Approaches to Construct Social Discount Rate. Sains Humanika, 8, 37-42. https://doi.org/10.11113/sh.v8n4-3.1079

Cooperate Finance Institute Website (n.d.). Discount Rate. https://corporatefinanceinstitute.com/resources/knowledge/finance/discount-rate

CREO (2020). An Investment Primer for Reforestation: Carbon Removal, Environmental and Social Impacts, and Financial Potential. https://static1.squarespace.com/static/53b153bde4b0eb409786a288/t/5e4da053ee5bb23 bd71a0928/1582145641950/CREO-WHITE+PAPER_Reforestation_05.pdf

Current, D., Scherr, S. J., \& Lutz, E. (1995). The Costs and Benefits of Agroforestry to Farmers. The World Bank Research Observers, 10, 151-180. https://doi.org/10.1093/wbro/10.2.151

Dale, V. H., \& Polasky, S. (2007). Measures of the Effects of Agricultural Practices on Ecosystem Services. Ecological Economics, 64, 286-296.

https://doi.org/10.1016/j.ecolecon.2007.05.009

Daujanov, A., Groeneveld, R., Pulatov, A., \& Heijman, W. J. M. (2016). Cost-Benefit Analysis of Conservation Agriculture Implementation in Syrdarya Province, Visegrad. Journal on Bioeconomy and Sustainable Development, 5, 48-52. https://doi.org/10.1515/vjbsd-2016-0009

David, R., Ngulube, P., \& Dube, A. (2013). A Cost Benefit Analysis of Document Management Strategies Used at a Financial Institution in Zimbabwe: A Case Study. South African Journal of Information Management, 15, a540. https://sajim.co.za/index.php/sajim/article/view/540 https://doi.org/10.4102/sajim.v15i2.540

de la Masselière, B. C., Bart, F., Racaud, S., Bonnassieux, A., \& Baron, C. (2017). Mountains and Urbanization in East Africa. In S. Racaud, B. Nakileza, F. Bart, \& B. C. Masselière (Eds.), Rural-Urban Dynamics in the East African Mountains (pp. 3-25). Mkuki na Nyota; IFRA. https://doi.org/10.4000/books.africae.1178 https://hal-univ-tlse2.archives-ouvertes.fr/hal-01897520/document

Degu, T. K., \& Megerssa, G. R. (2020). Role of Beekeeping in the Community Forest Conservation: Evidence from Ethiopia. Bee World, 97, 98-104. https://doi.org/10.1080/0005772X.2020.1825308

Do, H., Luedeling, E., \& Whitney, C. (2020). Decision Analysis of Agroforestry Options Reveals Adoption Risk for Resource-Poor Farmers. Agroforestry for Sustainable Development, 40, Article No. 20. https://doi.org/10.1007/s13593-020-00624-5 https://link.springer.com/article/10.1007/s13593-020-00624-5

EAC/UNEP/GRID-Arendal (2016). Sustainable Mountain Development in East Africa in a Changing Climate. Arusha, Nairobi and Arendal: East African Community, United Nations Environment Programme and GRID-Arendal.

Etikan, I., Alkassim, R., \& Abubakar, S. (2016). Comparison of Snowball Sampling and Sequential Sampling Technique. Biometrics \& Biostatistics International Journal, 3, Article No. 00055. https://doi.org/10.15406/bbij.2016.03.00055

European Commission, EC (2008). Guide to Cost Benefit Analysis of Investment ProjectsStructural Funds, Cohesion Fund and Investment for Pre-Accession (257 p.). European Commission, Directorate General Regional Policy.

Evans, D. (2007). Social Discount Rates for the European Union: New Estimates, In M. Florio (Ed.), Cost-Benefit Analysis and Incentives in Evaluation (Chapter 12, 15 p). Cheltenham: The Structural Funds of the European Union, Edward Elgar. 
Ewers, R. M., \& Didham, R. K. (2006). Confounding Factors in the Detection of Species Responses to Habitat Fragmentation. Biological Reviews, 81, 117-142. https://doi.org/10.1017/S1464793105006949

Fahrig, L. (2003). Effects of Habitat Fragmentation on Biodiversity. Annual Review of Ecology and Systematics, 34, 487-515. https://doi.org/10.1146/annurev.ecolsys.34.011802.132419

FAO (2020a). Global Forest Resources Assessment 2020: Main Report. Rome.

FAO (2020b). Transforming Agriculture and Food Systems: Halting Deforestation and Promoting Sustainable Production and Consumption of Forest Products.

Fernandez, R. (2009). Marshallian Agglomeration Economics and Entrepreneurship: The Spanish Case. Innovation, 1-30.

Fisher, I. (1930). The Theory of Interest. New York: Macmillan. http://www.econlib.org/library/YPDBooks/Fisher/fshToI.html

Florio, M., Finzi, U., Genco, M., Levarlet, F., Maffii, S., Tracogna, A., \& Vignetti, S. (1997). Guide to Cost-Benefit Analysis of Investment Projects. Prepared for Evaluation Unit DG Regional Policy European Commission, Structural Fund-ERDF, Cohesion Fund and ISPA.

https://ec.europa.eu/regional_policy/sources/docgener/guides/cost/guide02_en.pdf

Fudge, M. (2011). Cost-Benefit Analysis Approach to Measuring Performance. Public Administration Review, 71, 487-489. http://www.jstor.org/stable/23017507 https://doi.org/10.1111/j.1540-6210.2011.02371.x

Giama, X. (2017). Global Biodiversity Loss from Tropical Deforestation. PNAS, 114, 5775-5777. https://doi.org/10.1073/pnas.1706264114

Hanley, N. (2002). The Economic Value of Environmental Damage. In M. Bowman, \& A. Boyle (Eds.), Environmental Damage in International and Comparative Law: Problems of Definition and Valuation (Chapter 3). Oxford: Oxford University Press Scholarship. https://doi.org/10.1093/acprof:oso/9780199255733.003.0003

Harrison, E., \& Mdee, A. (2017). Successful Small-Scale Irrigation or Environmental Destruction? The Political Ecology of Competing Claims on Water in the Uluguru Mountains, Tanzania. Journal of Political Ecology, 24, 407-424.

https://www.researchgate.net/figure/Uluguru-Nature-Reserve-Source-UNR-no-date_fi g1_313613549 https://doi.org/10.2458/v24i1.20881

Heckathorn, D. D. (2015). Snowball versus Respondent-driven Sampling. Sociological Methodology, 41, 352-366. https://doi.org/10.1111/j.1467-9531.2011.01244.x

Jenkins, G. P., Primrose, M. M., Basikiti, V., \& Preotle, E. (2018). Cost Benefit Analysis of Agricultural Interventions to Enhance the Production of Cowpea, Groundnuts, Maize and Soybeans Value Chains in Nigeria. Development Discussion Paper: 2018-03, USAID-Learning, Evaluation, and Analysis Project (LEAP II), AID-OAA-I-12-00042/ AID-OAA-TO-14-00046. http://cri-world.com/publications/qed_dp_402.pdf

Johnston, R. J., Rolfe, J., Rosenberger, R. S., \& Brouwer, R. (2015). Introduction to Benefit Transfer Methods. In R. J. Johnston, J. Rolfe, R. S. Rosenberger, \& R. Brouwer (Eds.), Benefit Transfer of Environmental \& Resource Values (pp. 19-59). Berlin: Springer. https://doi.org/10.1007/978-94-017-9930-0

Kirzner, I. M. (1978). The Entrepreneurial Role in Menger's System. Atlantic Economic Journal, 6, 31-45. https://doi.org/10.1007/BF02313307

Krauss, J., Bommarco, R., Guardiola, M., Heikkinen, R. K., Helm, A., Kuussaari, M., Lindborg, R., Ockinger, E., Partel, M., Pino, J. et al. (2010). Habitat Fragmentation 
Causes Immediate and Time-Delayed Biodiversity Loss at Different Trophic Levels. Ecology Letters, 13, 597-605. https://doi.org/10.1111/j.1461-0248.2010.01457.x

Kuboja, N. M, Isinika, A. C., \& Kilima, F. T. M. (2017). Determinants of Economic Efficiency among Small-Scale Beekeepers in Tabora and Katavi Regions, Tanzania: A Stochastic Profit Frontier Approach. Development Studies Research, 4, 1-8. https://doi.org/10.1080/21665095.2017.1355738

Kula, E. (2006). The Social Discount Rate in Cost Benefit Analysis: The British Experience and Lessons to Be Learned. Working Paper No. 19, Fifth Milan European Economy Workshop, University of Milan, Italy, 26-27 May 2006, 26-27.

Lanctot, P. (2019). The Advantages and Disadvantages of the Internal Rate of Return Method. Chron.

https://smallbusiness.chron.com/types-project-appraisal-methodologies-14716.html

Langlois, R. N. (2002). Kirznerian Entrepreneurship and the Nature of the Firm. Journal des Economistes et des Etudes Humaines, 12, 1-8. https://doi.org/10.2202/1145-6396.1050

Laurance, W. F. et al. (2012). Averting Biodiversity Collapse in Tropical Forest Protected Areas. Nature, 489, 290-294. https://doi.org/10.1038/nature11318

Lazaro, V., Rajendran, S., Afari-Sefa, V., \& Kazuzuru, B. (2017). Analysis of Good Agricultural Practices in an Integrated Maize-Based Farming System. International Journal of Vegetable Science, 23, 598-604. https://doi.org/10.1080/19315260.2017.1341445

Ley, E. (2007). On the Improper Use of the Internal Rate of Return in Cost-Benefit Analysis. Washington DC: World Bank Institute.

Lyamuya, V. E., Noah, L. G., Kilasara, E. J., \& Burgess, N. D. (1994). Socio-Economic and Land Use Factors Affecting the Degradation of the Uluguru Mountains Catchment in Morogoro Region, Tanzania. Morogoro Regional Natural Resources Office, RSPB-UK.

Massawe, P. I., Mvena, A., Nyoki, D., \& Chambile, E. L. (2019). Effects of Anthropogenic Activities on Availability of Clean and Safe Water: A Case of Uluguru Forest Catchment Areas of Morogoro, Tanzania. South Asian Journal of Development Research, 1, 114-123.

Massawe, P. I., Nyoki, D., Mvena, A., \& Chambile, E. L. (2020). Assessments of Environmental Impacts of Uluguru North Water Catchment Forest Reserve in Morogoro, Tanzania. International Research Journal of Applied Sciences. https://scirange.com/pdf/irjas.2020.198.198.pdf

McFarlane, J. (2016). Economic Theories of Entrepreneurship. In N. Arshed, \& M. Danson (Eds.), Enterprise: Concepts and Issues (Chapter 2). Oxford: Goodfellow Publishers. https://doi.org/10.23912/978-1-910158-75-3-2880

Monga, K., \& Manocha, A. (2011). Adoption and Constraints of Beekeeping in District Panchkula, India. Livestock Research for Rural Development, 23, 103. http://www.lrrd.org/lrrd23/5/mong23103.htm

Mujuni, A., Natukunda, K., \& Kugonza, D. R. (2012). Factors Affecting the Adoption of Beekeeping and Associated Technologies in Bushenyi District, Western Uganda. Development, 24, 1-19.

Murray, G. F. (1991). The Tree Gardens of Haiti: Agroforestry among Caribbean Peasants. In D. Challinor, \& M. H. Frondorf (Eds.), Social Forestry, Communal and Private Management Strategies Compared, Case Studies (pp. 35-44). Washington DC: Sais-Johns Hopkins University.

http://users.clas.ufl.edu/murray/Research/Haiti/Tree_Gardens_of_Haiti.pdf 
National Geographic Website (n.d.).

https://www.nationalgeographic.com/science/earth/surface-of-the-earth/mountains/\#: :text=They\%20usually\%20have\%20steep\%2C\%20sloping,mountains\%20that $\% 20$ are $\%$ 20close\%20together

OMB, US Office of Management and Budget (2003). Circular A-4: Regulatory Analysis. Washington DC. https://obamawhitehouse.archives.gov/omb/circulars_a004_a-4/

Pananek, G. F. (1962). The Development of Entrepreneurship. American Economic Review, 52, 45-58.

Parker, S. C. (2018). Entrepreneurship and Economic Theory. Oxford Review of Economic Policy, 34, 540-564. https://doi.org/10.1093/oxrep/gry013

Piñeiro, V., Arias, J., Dürr, J., Elverdin, P., Ibáñez, A. M., Kinengyere, A., Opazo, C. M., Owoo, N., Page,J. R., Steven, D., Prager, S. D., \& Torero, M. (2020). A Scoping Review on Incentives for Adoption of Sustainable Agricultural Practices and their Outcomes. Nature Sustainability, 3, 809-820. https://doi.org/10.1038/s41893-020-00617-y

Plummer, M. L. (2009). Assessing Benefit Transfer for Valuation of Ecosystem Services. Frontiers in Ecology and the Environment, 7, 38-45. https://doi.org/10.1890/080091

Rahman, S., Rahman, M., Codilan, A., \& Farhana, K. (2007). Analysis of the Economic Benefits from Systematic Improvements to Shifting Cultivation and its Evolution towards Stable Continuous Agroforestry in the Upland of Eastern Bangladesh. The In ternational Forestry Review, 9, 536-547. http://www.jstor.org/stable/43740298 https://doi.org/10.1505/ifor.9.1.536

Rosenberger, R. S., \& Loomis, J. (2001). Benefit Transfer of Outdoor Recreation Use Values: A Technical Document Supporting the Forest Service Strategic Plan (2000 Revision). Gen Tech Rep RMRS-GTR-72, Fort Collins, CO: US Department of Agriculture, Forest Service, Rocky Mountain Research Station. https://doi.org/10.2737/RMRS-GTR-72

Sagastuy, M., \& Krause, T. (2019). Agroforestry as a Biodiversity Conservation Tool in the Atlantic Forest? Motivations and Limitations for Small-Scale Farmers to Implement Agroforestry Systems in North-Eastern Brazil. Sustainability, 11, 6932. https://doi.org/10.3390/su11246932

Sain, G., Loboguerrero, A. M., Corner-Dolloff, C., Lizarazo, M., Nowak, A., MartínezBarón D., \& Andrieu, N. (2017). Costs and Benefits of Climate-Smart Agriculture: The Case of the Dry Corridor in Guatemala. Agricultural Systems, 151, 163-173. https://doi.org/10.1016/j.agsy.2016.05.004

Secretariat of the Convention on Biological Diversity (n.d.). https://www.cbd.int/undb/media/factsheets/undb-factsheet-mountains-en.pdf

Śledzik, K. (2013). Schumpeter's View on Innovation and Entrepreneurship. SSRN Electronic Journal. https://doi.org/10.2139/ssrn.2257783

Smith, W., \& Chimucheka, T. (2014). Entrepreneurship, Economic Growth and Entrepreneurship Theories. Mediterranean Journal of Social Sciences, 5, 160-168. https://doi.org/10.5901/mjss.2014.v5n14p160

Swinkels, R. A., \& Scherr, S. J. (1991). Economic Analysis of Agroforestry Technologies: An Annotated Bibliography. Nairobi: ICRAF.

The Economic Times (2020). Cost Benefit Analysis. https://economictimes.indiatimes.com/definition/cost-benefit-analysis

Tilman, D., \& Clark, M. (2014). Global Diets Link Environmental Sustainability and Human Health. Nature, 515, 518-522. https://doi.org/10.1038/nature13959

Tilman, D., May, R. M., Lehman, C. L., \& Nowak, M. A. (1994). Habitat Destruction and 
the Extinction Debt. Nature, 371, 65-66. https://doi.org/10.1038/371065a0

Tscharntke, T., Sekercioglu, C. H., Dietsch, T. V., Sodhi, N. S., Hoehn, P., \& Tylianakis, J. M. (2008). Landscape Constraints on Functional Diversity of Birds and Insects in a Tropical Agroecosystem. Ecology, 89, 944. https://doi.org/10.1890/07-0455.1

Tschinkel, H. (1987). Tree Planting by Small Farmers in Upland Watersheds: Experience in Central America. International Tree Crops Journal, 4, 249-268. https://doi.org/10.1080/01435698.1987.9752827

Tutuba, N., \& Vanhaverbeke, W. (2018). Beekeeping in Tanzania: Why Is Beekeeping Not Commercially Viable in Mvomero? Afrika Focus, 31, 213-239. https://doi.org/10.21825/af.v31i1.9047

URT (2001). National Biodiversity Strategy and Action Plan. Dar es Salaam: Vice President's Office, Division of Environment.

URT (2007). National Adaptation Programme of Action (NAPA). Dar es Salaam: Division of Environment, Vice President's Office.

URT (2012). National Climate Change Strategy. Dar es Salaam: Vice President's Office, Division of Environment.

Van Thang, H., Van Do, T., Kozan, O., \& Catacutan, D. C. (2015). Cost-Benefit Analysis for Agroforestry Systems in Vietnam. Asian Journal of Agricultural Extension, Economics \& Sociology, 5, 158-165. https://doi.org/10.9734/AJAEES/2015/15750

Venter, O. et al. (2014). Targeting Global Protected Area Expansion for Imperilled Biodiversity. PLOS Biology, 12, e1001891. https://doi.org/10.1371/journal.pbio.1001891

Vergara, N. T., \& MacDicken, K. G. (1990). Extension and Agroforestry Technology Delivery to Farmers. In K. G. MacDicken, \& N. T. Vergara (Eds.), Agroforestry: Classification and Management (pp. 354-373). New York: John Wiley and Sons.

Vogt, P., Riitters, K., Caudullo, G., \& Eckhardt, B. (2019). FAO-State of the World's Forests: Forest Fragmentation. EUR 29972 EN, Luxembourg: Publications Office of the European Union.

Wainaina, P., Gituku, E., \& Minang, P. (2020). An Exploratory Study of Cost-Benefit Analysis of Landscape Restoration. Working Paper Number 306, Nairobi: World Agroforestry. https://doi.org/10.5716/WP20014.PDF

William, C. (2010). Ecology, Conservation and Climate-Fire Challenges on Uluguru Mountain Biodiversity Hotspot, Tanzania. PhD Thesis, Minneapolis, MN: University of Minnesota, U.S.A.

Winfree, R. (2020). The Conservation and Restoration of Wild Bees. Annals of the New York Academy of Sciences, 1195, 169-197. https://doi.org/10.1111/j.1749-6632.2010.05449.x

Yanda, P. Z., \& Munishi, P. K. T. (2007). Hydrologic and Land Use/Cover Change Analysis for the Ruvu River (Uluguru) and Sigi River (East Usambara) Watersheds. Dar es Salaam: WWF/CARE.

Zinngrebe, Y., Borasino, E., Chiputwa, B., Dobie, P., Barcia, E., Gassner, A., Kihumuro, P., Komarudin, H., Liswanti, N., Makui, P., Plieninger, T., Winter, E., \& Hauck, J. (2020). Agroforestry Governance for Operationalizing the Landscape Approach: Connecting Conservation and Farming Actors. Sustainability Science, 15, 1417-1434. https://link.springer.com/article/10.1007/s11625-020-00840-8 https://doi.org/10.1007/s11625-020-00840-8 